\title{
ОСОБЛИВОСТІ СИНДРОМУ ЕМОЦІЙНОГО ВИГОРАННЯ У МЕДИЧНИХ СЕСТЕР ТЕРАПЕВТИЧНИХ ТА ХІРУРГІЧНИХ ВІДДІЛЕНЬ
}

\author{
Т. М. Драга, Т. Б. Ханас, І. Я. Криницька \\ Комунальна установа «Міська клінічна лікарня № 10», м. Одеса \\ Тернопільська обласна комунальна клінічна психоневрологічна лікарня \\ ДВНЗ «Тернопільський державний медичний університет \\ імені І. Я. Горбачевського МОЗ Украӥни»
}

У статті розглянуто сучасні теоретичні підходи до синдрому емоційного вигорання як форми професійної деформації медичних працівників. Звернено увагу на особливості вираження синдрому емоційного вигорання у медичних сестер терапевтичних та хірургічних відділень.

\section{THE FEATURES OF EMOTIONAL BURNOUT SYNDROME IN NURSES OF THERAPEUTIC AND SURGICAL DEPARTMENTS}

\author{
T. M. Draga, T. B. Khanas, I. Ya. Krynytska \\ Municipal institution "City Clinical Hospital No. 10», Odesa \\ Ternopil Regional Communicative Clinical Psychoneurological Hospital \\ I. Horbachevsky Ternopil State Medical University
}

The article presents current theoretical approaches to the syndrome of emotional burnout as a form of professional deformation of medical stuff. Attention is drawn to the features of severity of emotional burnout syndrome in nurses of therapeutic and surgical departments.

Вступ. Актуальність дослідження особливостей синдрому емоційного вигорання (CEB) у медичних сестер пов'язана з масовими проявами цієї патології серед медичних працівників. Інтенсифікація професійної діяльності, розширення переліку обов'язків, високе виробниче навантаження, цілодобові чергування медичних сестер - всі ці фактори призводять до розвитку психоемоційного напруження. На фахівців-медиків покладають велику відповідальність за життя і здоров'я людини, що спричиняє ризик виникнення CEB [1-3]. Характер професійної діяльності медсестер терапевтичних та хірургічних відділень відрізняється, що може відобразитися на ступені вираження проявів CEB.

За визначенням Всесвітньої організації охорони здоров'я, СЕВ - це фізичне, емоційне або мотиваційне виснаження, яке характеризується порушенням продуктивності в роботі, втомою, безсонням, підвищеною схильністю до соматичних захворювань, а також вживанням алкоголю або інших психоактивних речовин для отримання тимчасового полегшення, що

() Т. М. Драга, Т. Б. Ханас, І. Я. Криницька, 2018 має тенденцію до розвитку фізичної залежності та в окремих випадках навіть суїцидальної поведінки [4].

Мета дослідження - визначити рівень емоційного вигорання у початковій фазі напруження у медичних сестер терапевтичного та хірургічного профілів.

Основна частина. Всього було обстежено 120 медичних сестер. За віком респондентів поділили таким чином: 20-29 років - 27,7 \%, 30-39 років - 40,0 \%, 40-49 років - 16,7 \%, 50-59 років - 15,6 \%. Середню спеціальну освіту мали 73,4 \% респондентів, вищу медичну освіту - 8,9 \% медсестер, незакінчену вищу освіту - 17,7 \% респондентів. На момент проведення анкетування більшість медичних сестер мала кваліфікаційну категорію (84,4 \%). Особи, які мали вищу кваліфікаційну категорію, склали 39,5 \%, першу - 34,2 \% і другу - 26,3 \%. Середній загальний медичний стаж роботи респондентів склав $(20 \pm 3,1)$ року, а в відділенні - $(14,5 \pm 2,1)$ року. Соціальний статус визначений в основному заміжніми жінками. 58,9 \% респондентів заміжні офіційно, 3,3 \% проживають у цивільному шлюбі, 24,0 \% - не одружені, 13,8 \% - розлучені. 
Для діагностики рівня емоційного вигорання у медичних сестер використовували опитувальник «Методика діагностики емоційного вигорання» В. В. Бойка [5].

Ця методика дозволяє отримати докладну картину синдрому емоційного вигорання особистості, виявити провідні симптоми емоційного вигорання, що становлять три фази його формування: фазу напруження (переживання психотравмуючих обставин, незадоволення собою, «загнаності в клітку», тривоги й депресії); фазу резистенції (неадекватного вибіркового емоційного реагування, емоційно-моральної дезорієнтації, розширення сфери економії емоцій, редукції професійних обов'язків); фазу виснаження (емо- ційного дефіциту і відстороненості, деперсоналізації, психосоматичних і психовегетативних порушень).

Фаза напруження - початкова стадія емоційного вигорання. Вона перебуває в стадії формування у 33 \% медсестер терапевтичного і 23 \% медсестер хірургічного профілів. Ця фаза сформувалась у $77 \%$ медсестер хірургічного профілю (табл. 1). Таким чином, ступінь вираження емоційного вигорання в фазі напруження на 67 \% вищий у співробітників хірургічних відділень. Середній показник сформованості фази напруження у медсестер терапевтичних відділень дорівнює 30 балів, а у медсестер хірургічних відділень 75 балів, що свідчить про більш високий ступінь сформованості у них фази напруження.

Таблиця 1. Результати дослідження емоційного вигорання у фазі напруження у медсестер терапевтичного та хірургічного профілів

\begin{tabular}{|c|c|c|c|c|}
\hline \multirow{2}{*}{ Фаза / Симптоми } & \multicolumn{2}{|c|}{ Терапевтичні відділення } & \multicolumn{2}{|c|}{ Хірургічні відділення } \\
\hline & особи & $\%$ & особи & $\%$ \\
\hline $\begin{array}{l}\text { I. Напруження: } \\
\text { - фаза не сформувалася } \\
\text { - фаза в стадії формування } \\
\text { - сформована фаза }\end{array}$ & $\begin{array}{c}40 \\
20 \\
0\end{array}$ & $\begin{array}{c}67 \\
33 \\
0\end{array}$ & $\begin{array}{c}0 \\
14 \\
46\end{array}$ & $\begin{array}{c}0 \\
23 \\
77\end{array}$ \\
\hline $\begin{array}{l}\text { 1. Переживання при психотравмуючих обставинах: } \\
\text { - несформований симптом } \\
\text { - симптом у процесі формування } \\
\text { - сформований симптом }\end{array}$ & $\begin{array}{c}38 \\
0 \\
22\end{array}$ & $\begin{array}{c}63 \\
0 \\
13\end{array}$ & $\begin{array}{c}0 \\
4 \\
56\end{array}$ & $\begin{array}{c}0 \\
7 \\
93\end{array}$ \\
\hline $\begin{array}{l}\text { 2. Незадоволення собою: } \\
\text { - несформований симптом } \\
\text { - симптом у процесі формування } \\
\text { - сформований симптом }\end{array}$ & $\begin{array}{c}56 \\
4 \\
0\end{array}$ & $\begin{array}{c}93 \\
7 \\
0\end{array}$ & $\begin{array}{l}10 \\
34 \\
16\end{array}$ & $\begin{array}{l}17 \\
56 \\
27\end{array}$ \\
\hline $\begin{array}{l}\text { 3. «Загнаність в клітку»: } \\
\text { - несформований симптом } \\
\text { - симптом у процесі формування } \\
\text { - сформований симптом }\end{array}$ & $\begin{array}{l}30 \\
12 \\
18\end{array}$ & $\begin{array}{l}50 \\
20 \\
30\end{array}$ & $\begin{array}{c}4 \\
14 \\
42\end{array}$ & $\begin{array}{c}7 \\
23 \\
70\end{array}$ \\
\hline $\begin{array}{l}\text { 4. Тривога і депресія: } \\
\text { - несформований симптом } \\
\text { - симптом у процесі формування } \\
\text { - сформований симптом }\end{array}$ & $\begin{array}{c}60 \\
0 \\
0\end{array}$ & $\begin{array}{c}100 \\
0 \\
0\end{array}$ & $\begin{array}{c}0 \\
24 \\
36\end{array}$ & $\begin{array}{c}0 \\
40 \\
60\end{array}$ \\
\hline
\end{tabular}

Висновки. Встановлено, що рівень вираження синдрому емоційного вигорання достовірно вищий у медичних сестер хірургічного профілю відносно працівників терапевтичних відділень.

\section{СПИСОК ЛІТЕРАТУРИ}

1. Вдовина Д. М. Синдром «эмоционального выгорания» и конфликтное поведение в профессиональной деятельности медицинских сестер / Д. М. Вдовина // Бюллетень медицинских Интернет-конференций. - 2014. - Т. 4, № 11. - С. 137.

2. Миргород Н. В. Синдром профессионального выгорания у медицинских сестер / Н. В. Миргород // Головна медична сестра : спеціалізоване видання для головних медичних сестер. - 2013. - № 4. - С. 20.
3. Шатило В.Й. Синдром емоційного вигорання в професії медичної сестри / В. Й. Шатило, А. А. Мельник // Головна медична сестра : спеціалізоване видання для головних медичних сестер. - 2012. - № 12. - С. 41.

4. Касьянова А. Ю. Особливості професійного вигорання медичного персоналу, який працює з пацієнтами 3 вродженими вадами серця / А. Ю. Касьянова // Медична психологія. - 2015. - № 2. - С. 23-26.

5. Дудяк В. Емоційне вигорання / В. Дудяк. - К. : Главник, 2007. -126 C. 